\title{
The in vitro effect of progesterone on the orexin system in porcine uterine tissues during early pregnancy
}

\author{
Kamil Dobrzyn, Nina Smolinska* (D), Marta Kiezun, Karol Szeszko, Edyta Rytelewska, Katarzyna Kisielewska, \\ Marlena Gudelska and Tadeusz Kaminski
}

\begin{abstract}
Background: Orexin A (OXA) and orexin B (OXB) are hypothalamic-derived peptides that participate in the regulation of energy metabolism, food intake and reproductive function by influencing the hypothalamic-pituitary-ovarian axis. Orexins are also produced in the endometrium, myometrium and placenta, which suggests that they could act as a link between energy metabolism and the reproductive system. Changes in the expression of orexin and the orexin receptor genes and proteins during the oestrous cycle and early gestation in pigs imply that orexin activity may be regulated by local factors within the uterus. The aim of this study was to investigate the influence of progesterone $\left(P_{4}\right)$ on the expression of orexin system genes, and proteins in the porcine uterus during early gestation. Gene expression was analyzed by real-time PCR. Adiponectin secretion was determined by ELISA, and the receptors proteins content was defined using western blot analysis.
\end{abstract}

Results: In the endometrium, $\mathrm{P}_{4}$ enhanced OXA secretion on days 10 to 11 of gestation and OXB secretion on days 12 to 13 . In the myometrium, $\mathrm{P}_{4}$ inhibited the secretion of both orexins on days 15 to 16 and OXB secretion also on days 12 to 13 . In the endometrium, $\mathrm{P}_{4}$ inhibited the expression of orexin receptor 1 (OX1R) protein at nearly all times analyzed, whereas the expression of orexin receptor 2 (OX2R) protein was inhibited only on days 15 to 16 of gestation. In the myometrium, $\mathrm{P}_{4}$ stimulated OX1R protein expression on days 12 to 13 and 15 to 16 of gestation and inhibited OX1R protein expression on days 27 to 28. The expression of OX2R protein in the myometrium increased on days 12 to 13 and decreased on days 10 to 11 and 15 to 16 .

Conclusions: The results indicate that $\mathrm{P}_{4}$ could regulate the expression of the orexin system in the porcine uterus during early pregnancy, which suggests the presence of a local feedback loop that could play an important role in the regulation of maternal metabolism during pregnancy. The findings may contribute to the existing knowledge of the mechanisms linking maternal energy metabolism with the regulation of the reproductive system during pregnancy.

Keywords: Early pregnancy, Orexins, Orexin receptors, OXA, OXB, Porcine uterus, Progesterone

\section{Background}

It is generally acknowledged that reproductive success of animals is largely determined by their nutritional status. Orexin A (OXA) and orexin B (OXB) are hypothalamic neuropeptides which are derived by proteolytic cleavage from a common 130-amino acid precursor called

\footnotetext{
*Correspondence: nina.smolinska@uwm.edu.pl Department of Animal Anatomy and Physiology, Faculty of Biology and Biotechnology, University of Warmia and Mazury in Olsztyn,
} Oczapowskiego 1A, 10-719 Olsztyn-Kortowo, Poland prepro-orexin (PPO). OXA is a 33-amino-acid peptide with molecular mass of $3.5 \mathrm{kDa}$, whereas OXB is a 28 -amino-acid peptide with molecular mass of $2.9 \mathrm{kDa}$. There is around $46 \%$ homology between OXA and OXB. Orexin activity is mediated by G-protein-coupled receptors: orexin receptor type 1 (OX1R) and orexin receptor type 2 (OX2R). OX1R is highly selective for OXA, whereas OX2R has a similar affinity for both OXA and OXB $[1,2]$.

Current data suggest that orexins may influence reproductive function. Orexins were found to participate 
in the control of the hypothalamic-pituitary-ovarian axis [3-9]. The hormones and their receptors are also expressed locally in rat and porcine ovaries $[3,7,10]$. The elements of the orexin system have been observed in feline, canine and human placenta $[11,12]$. The expression of orexin system genes and proteins was also confirmed in the porcine uterus, conceptus and trophoblasts $[13,14]$. Our previous research demonstrated changes in the endometrial and myometrial expression of orexin and orexin receptor genes and proteins during the oestrous cycle and early pregnancy, which indicates that orexin expression could be dependent on the local hormonal status, including the presence and concentration of steroid hormones [7, 13, 14].

Steroids are one of the most important factors in the porcine reproductive system, and they participate in the maternal recognition and maintenance of pregnancy [15]. Steroidogenesis is not limited to the ovaries and adrenals, and it could also take place in the uterus [16]. The regulation of orexin and orexin receptor expression in the uterus is poorly understood. The aim of this study was to investigate the influence of progesterone $\left(\mathrm{P}_{4}\right)$ on the expression of prepro-orexin $(P P O), O X 1 R$ and $O X 2 R$ genes, on OXA and OXB secretion in vitro and the expression of OX1R and OX2R proteins in the porcine endometrium and myometrium on days 10 to 11,12 to 13,15 to 16 and 27 to 28 of pregnancy and on days 10 to 11 of the oestrous cycle.

\section{Methods}

\section{Animals and tissue collection}

All studies were conducted in accordance with ethical standards of the Animal Ethics Committee at the University of Warmia and Mazury in Olsztyn, Poland. Mature gilts (Large White $x$ Polish Landrace) at the age of 7-8 months and weight of 120-130 kg descended from private breeding farm were used in the study. Twenty-five gilts were assigned to one of five experimental groups ( $\mathrm{n}=5$ per group) as follows: 10 to 11 (the beginning of maternal recognition of pregnancy), 12 to 13 (the end of maternal recognition of pregnancy), 15 to 16 (implantation) and 27 to 28 (the end of implantation) days of pregnancy and days 10 to 11 of the oestrous cycle (midluteal phase, connected with the period of fully active corpora lutea, corresponding to the activity of corpora lutea during pregnancy). Cyclic gilts were daily observed for estrus behavior in the presence of an intact boar. The day of onset of the second estrus was marked as day 0 of the oestrous cycle. The phase of the oestrous cycle was also confirmed on the basis of morphology of the ovaries [17]. The level of serum $\mathrm{P}_{4}$ was determined to confirm the phase of the oestrous cycle. The results of $\mathrm{P}_{4}$ measure were published in another study conducted on the same animals [18]. In the case of pregnant gilts, the day after coitus was marked as the first day of pregnancy. Insemination was performed on days 1 to 2 of the oestrous cycle. Pregnancy was confirmed by the presence of conceptuses. Uteri collected after slaughter were placed in ice-cold PBS supplemented with $100 \mathrm{IU} / \mathrm{mL}$ penicillin and $100 \mu \mathrm{g} / \mathrm{mL}$ streptomycin and transported to the laboratory on ice within $1 \mathrm{~h}$ for in vitro tissue culture.

\section{Tissue cultures}

Endometrial and myometrial explants were performed based on a modification of the technique described by Franczak [19] with the modification of Smolinska et al. [20]. The endometrial and myometrial tissues, from the middle of uterine horns were cut into small, irregular slices with about $3 \mathrm{~mm}$ of thickness (100 $\mathrm{mg} \pm 10 \%)$. On days 27 to 28 of pregnancy, conceptuses and trophoblasts were dissected from the endometrium. All slices of the uteri on days 27 to 28 of pregnancy were collected from the implantation sites. Tissue explants were washed three times in medium M199 (Sigma-Aldrich, USA). Endometrial and myometrial slices were placed in the separate sterile culture vials with $2 \mathrm{~mL}$ medium 199 containing 0.1\% BSA (MP Biomedicals, USA), 5\% dextran/charcoalstripped newborn calf serum (Sigma-Aldrich), penicillin $(100 \mathrm{IU} / \mathrm{mL})$ and streptomycin $(100 \mu \mathrm{g} / \mathrm{mL})$. Cultures were preincubated for $2 \mathrm{~h}\left(37{ }^{\circ} \mathrm{C}, 95 \% \mathrm{O}_{2}, 5 \% \mathrm{CO}_{2}\right)$. To determine the influence of $\mathrm{P}_{4}$ on $P P O, O X 1 R$ and $O X 2 R$ genes expression, OX1R and OX2R protein expression and OXA and OXB secretion, endometrial and myometrial slices were treated with $\mathrm{P}_{4}$ (Sigma-Aldrich) at the concentration of 10, 100 and $1000 \mathrm{nM}$ and incubated for another $24 \mathrm{~h}$ at the same conditions. The doses of $\mathrm{P}_{4}$ were chosen according to Blitek et al. [21]. Control tissues were incubated without any treatment. Our preliminary studies indicated that the influence of $\mathrm{P}_{4}$ solvent $(0.00094 \%$, $0.0094 \%$ and $0.094 \%$ of ethanol for 10,100 and $1000 \mathrm{nM}$ of $\mathrm{P}_{4}$ doses, respectively) on gene/protein expression and hormone secretion was negligible. All cultures were prepared in duplicates in five separate experiments for each group $(n=5)$. At the end of the experiment, the media were collected and stored at $-20{ }^{\circ} \mathrm{C}$. Endometrial and myometrial slices were frozen and stored at $-80^{\circ} \mathrm{C}$ for further analyses. The viability of slices was monitored by measuring lactate dehydrogenase (LDH) activity in media after $2 \mathrm{~h}$ of preincubation as well as at the end of the treatment period. The release of LDH was performed using a Liquick Cor-LDH kit (Cormay, Poland) following the manufacturer's instructions. The activity of LDH during the slices culture was compared to its activity in medium obtained after destruction of endometrial and myometrial cells by homogenization (positive control for causing cell death and the maximal release 
of LDH). Mean activity of LDH in cultured slices after treatment period was $55.1 \pm 4.5 \mathrm{U} / \mathrm{L}$ for endometrium (1.8\% of maximal release of LDH after total endometrial cells destruction) and $34.1 \pm 4.9 \mathrm{U} / \mathrm{L}$ for myometrium (1.7\% of maximal release of $\mathrm{LDH}$ after myometrial cells destruction).

\section{Quantitative real-time PCR}

Total RNA was extracted from tissues using peqGOLD TriFast isolation system (Peqlab, Germany) according to the manufacturer's instructions. RNA purity and quantity were measured spectrophotometricaly (Infinite M200 Pro, Tecan, Switzerland). One microgram of RNA was used in the reaction of reverse transcription in a total volume of $20 \mu \mathrm{L}$ with $0.5 \mu \mathrm{g}$ oligo $(\mathrm{dT})_{15}$ (Roche, Switzerland). The reaction was prepared using Omniscript RT Kit (Qiagen, USA) at $37^{\circ} \mathrm{C}$ for $1 \mathrm{~h}$ and was terminated by the incubation at $93{ }^{\circ} \mathrm{C}$ for $5 \mathrm{~min}$. Quantitative real-time PCR analysis was carried out using PCR System 7300 and Power SYBR Green Master Mix (Applied Biosystems, USA), as described previously [22]. Specific primer pairs used to amplify parts of $P P O, O X 1 R, O X 2 R$, cyclophilin $(P P I A)$ and $\beta$-actin $(A C T B)$ genes are detailed in Table 1. The PPIA and ACTB genes, which are expressed constitutively, were used as an internal control to verify the method. During the preliminary experiments it was found that expression of PPIA and ACTB was very similar in the endometrium and myometrium and was stable during the oestrous cycle and pregnancy and with treatments. The PCR reaction mixtures contained $10 \mathrm{ng}$ of cDNA, primers, $12.5 \mu \mathrm{L}$ Power SYBR Green PCR Master Mix (Applied Biosystems), and RNase free water at the final volume of $25 \mu \mathrm{L}$. Real-time PCR reaction conditions for $P P O, O X 1 R$ and $O X 2 R$ were as follows: enzyme activation and initial denaturation at $95{ }^{\circ} \mathrm{C}$ for $10 \mathrm{~min}$, afterward, 40 cycles of denaturation at $95^{\circ} \mathrm{C}$ for $15 \mathrm{~s}$, and annealing at $60^{\circ} \mathrm{C}$ for $1 \mathrm{~min}$. For PPIA reaction conditions were as follows: $50{ }^{\circ} \mathrm{C}$ for $2 \mathrm{~min}$, then enzyme activation and initial denaturation at $95{ }^{\circ} \mathrm{C}$ for $10 \mathrm{~min}$, afterward, 40 cycles of denaturation at $95{ }^{\circ} \mathrm{C}$ for $15 \mathrm{~s}$, and annealing at $60{ }^{\circ} \mathrm{C}$ for $1 \mathrm{~min}$. For $A C T B$ reaction conditions were as follows: enzyme activation and initial denaturation at $95{ }^{\circ} \mathrm{C}$ for $10 \mathrm{~min}$, followed by 40 cycles of denaturation at $95{ }^{\circ} \mathrm{C}$ for $15 \mathrm{~s}$, annealing at $61^{\circ} \mathrm{C}$ for $1 \mathrm{~min}$ and elongation at $72{ }^{\circ} \mathrm{C}$ for $1 \mathrm{~min}$. Negative controls were performed in which cDNA was substituted by water, or reverse transcription was not performed before PCR. All samples were prepared in duplicates. The specificity of amplification was tested at the end of the reaction by the analysis of melting-curve. Product purity was confirmed by agarose gel electrophoresis. Calculation of the relative expression levels of PPO, OX1R and $O X 2 R$ were conducted based on the comparative cycle threshold method $(\triangle \triangle \mathrm{CT})$, and normalized using the geometrical means of reference gene expression levels: PPIA and $A C T B$.

\section{Enzyme-linked immunosorbent assay (ELISA) of OXA and OXB}

The level of OXA and OXB protein concentrations in the culture media was determined using commercial ELISA kit (NeoBiolab, USA) according to the manufacturer's protocol. The range of standard curves was $0.5-10 \mathrm{ng} /$ $\mathrm{mL}$. The sensitivity of the assays was approximately $0.1 \mathrm{ng} / \mathrm{mL}$. The sensitivity of this assays was defined as the lowest protein concentration that could be differentiated from zero samples. Absorbance values were measured at $450 \mathrm{~nm}$ using Infinite M200 PRO reader with Tecan i-control software (Tecan). The data was linearized by plotting the log of OXA or OXB concentration versus the log of the optical density and the best fit line was determined by regression analysis. Intra- and interassay coefficients of variation of the OXA ELISA assay was $3.08 \% \pm 0.97$ and $3.45 \%$, respectively. For the OXB ELISA

Table 1 Characteristics of primers used in the study of gene expression in porcine endometrial and myometrial explants

\begin{tabular}{|c|c|c|c|c|c|}
\hline Gene & Primers sequences & Accession number & $\begin{array}{l}\text { Complementary } \\
\text { position }\end{array}$ & Primer, $\mathrm{nM}$ & References \\
\hline \multirow[t]{2}{*}{ PPO } & F: 5'-AAGACGACACCCTTCCTGGAGAC-3' & EF434655 & $F: 41-63$ & 500 & {$[9]$} \\
\hline & R: 5'-TGATTGCCAGCGCCGTGTAGCA-3' & & $R: 240-261$ & 500 & \\
\hline \multirow[t]{2}{*}{ OXIR } & F: 5'-ACCGCTGGTATGCCATCTACCAC-3' & AF097995 & $F: 27-49$ & 500 & [5] \\
\hline & R: 5'-ATAGAGGTCATCTGCCCAGCGTTCA-3' & & $R: 208-232$ & 500 & \\
\hline \multirow[t]{2}{*}{$O \times 2 R$} & F: 5'-GACATCACGGAGACCTGGTTCTTC-3' & AF059740 & F: $30-53$ & 500 & [5] \\
\hline & R: 5'-GATGTAGGAGACGATCCAGATGATGAC-3' & & $R: 207-233$ & 500 & \\
\hline \multirow[t]{2}{*}{ PPIA } & F: 5'-GCACTGGTGGCAAGTCCAT-3' & AY266299 & F: 219-237 & 300 & {$[42]$} \\
\hline & R: 5'-AGGACCCGTATGCTTCAGGA-3' & & $R: 269-299$ & 300 & \\
\hline \multirow[t]{2}{*}{ ACTB } & F: 5'-ACATCAAGGAGAAGCTCTGCTACG-3' & U07786 & F: 266-289 & 500 & [43] \\
\hline & R: 5'-GAGGGGCGATGATCTTGATCTTCA-3' & & $R: 608-631$ & 500 & \\
\hline
\end{tabular}


assay intra- and interassay coefficients of variation was $4.66 \% \pm 1.23$ and $7.87 \%$, respectively.

\section{Protein isolation and western blotting}

The endometrial and myometrial explants, obtained from the tissue cultures were homogenized on ice with the cold Total Protein Extraction Kit lysis buffer (Genoplast, Poland) in the presence of peptidase and phosphatase inhibitors (Sigma-Aldrich, USA), and incubated on ice for $30 \mathrm{~min}$. The lysates were cleared by centrifugation at $10,000 \times g$ for $2 \times 10 \mathrm{~min}$ at $4{ }^{\circ} \mathrm{C}$. The supernatants were stored at $-80{ }^{\circ} \mathrm{C}$ for further study. The protein concentrations were determined by the Bradford dye-binding procedure with the dilutions of bovine serum albumin (BSA) as standards.

Western blotting analysis was performed as described by Smolinska et al. [23]. Equal amounts $(40 \mu \mathrm{g})$ of endometrial and myometrial lysates were resolved by SDSPAGE electrophoresis in $12.5 \%$ polyacrylamide gel for separating OX1R, OX2R and actin proteins and transferred onto nitrocellulose membrane (Whatman, USA). Membranes were blocked for $4 \mathrm{~h}$ at $4{ }^{\circ} \mathrm{C}$ in Tris-buffered saline Tween-20 containing 5\% skimmed milk powder. After blocking, membranes were incubated for $12 \mathrm{~h}$ at $4{ }^{\circ} \mathrm{C}$ with sheep polyclonal antibodies to OX1R at a dilution of 1:100 (Abcam, UK), mouse polyclonal antibodies to OX2R at a dilution of 1:300 (Abcam, UK), or rabbit polyclonal antibodies to actin diluted 1:200 (SigmaAldrich, USA), which were used as a control for equal loading as well as to quantify porcine OX1R and OX2R proteins. To identify immunoreactive products, membranes were incubated for $2 \mathrm{~h}$ at RT with rabbit antisheep IgG for OX1R or goat anti-mouse IgG for OX2R (Santa Cruz Biotechnology, USA; diluted 1:500) or goat anti-rabbit IgG for actin conjugated with alkaline phosphatase (Santa Cruz Biotechnology, USA; dilution 1:2000). Nonspecific foetal calf serum (MP Biomedicals) was used instead of primary antibodies to produce negative control blots. Visualization of immunocomplexes was carried out using 4-nitroblue tetrazolium chloride (NBT) and 5-bromo-4-chloro-3-indolyl phosphate (BCIP), according to the manufacture's protocol (Promega, USA). The results of the analysis were quantified by densitometric scanning of membranes with GelScan for Windows version 1.45 software (Kucharczyk, Poland). Data were expressed as a ratio of OX1R or OX2R protein relative to actin protein in arbitrary optical density units.

\section{Statistical analysis}

Statistical analysis was performed using the Statistica software (StatSoft Inc., USA). All variables were analyzed using descriptive statistics (mean, standard deviation, sample minimum, and sample maximum). To determine the differences in genes expression and proteins concentration between control groups and $\mathrm{P}_{4}$ treated groups, one-way ANOVA followed by the Fisher's LSD post-hoc test were used. The model included the effect of $\mathrm{P}_{4}$ in three different concentrations treatment. Results were reported as the mean \pm SEM from five independent observations. Values for $\mathrm{P}<0.05$ were considered statistically significant.

\section{Results}

The effect of $\mathrm{P}_{4}$ on $P P O$ gene expression and OXA and OXB proteins secretion by the endometrial and myometrial tissue explants

In the endometrial tissue explants, on days 10 to 11 of pregnancy, $\mathrm{P}_{4}$ decreased $P P O$ gene expression (10, 100 and $1000 \mathrm{nM})$ and increased OXA (100 nM) secretion (Fig. 1a, b). On days 12 to 13 of pregnancy, $\mathrm{P}_{4}$ at the dose of $10 \mathrm{nM}$ decreased, whereas at the dose of $100 \mathrm{nM}$ increased $P P O$ gene expression. On those days, $\mathrm{P}_{4}$ $(100 \mathrm{nM})$ stimulated endometrial OXB secretion (Fig. 1a, c). On days 15 to 16 of pregnancy, $\mathrm{P}_{4}(100,1000 \mathrm{nM})$ caused a decrease in $P P O$ gene expression (Fig. 1a). Similarly, on days 27 to 28 of pregnancy, $\mathrm{P}_{4}(10,100 \mathrm{nM})$ inhibited the gene expression (Fig. 1a). On days 10 to 11 of the oestrous cycle, $\mathrm{P}_{4}(10$ and $1000 \mathrm{nM})$ stimulated $P P O$ gene expression (Fig. 1a) $(\mathrm{P}<0.05)$.

In the myometrium, on days 10 to 11 of pregnancy, $\mathrm{P}_{4}(1000 \mathrm{nM})$ caused a decrease in $P P O$ mRNA content (Fig. 2a). On days 12 to 13 of pregnancy, $\mathrm{P}_{4}$ inhibited $P P O$ gene expression $(100,1000 \mathrm{nM})$ and OXB secretion $(10,1000 \mathrm{nM})$ (Fig. 2a, c). On days 15 to 16 of gestation, $\mathrm{P}_{4}$ at the dose of $100 \mathrm{nM}$ stimulated, but at the dose of $1000 \mathrm{nM}$ inhibited $P P O$ gene expression. On those days, $\mathrm{P}_{4}$ inhibited the myometrial secretion of both, OXA $(1000 \mathrm{nM})$ and OXB (100 nM) (Fig. 2a-c). On days 27 to 28 of gestation, $\mathrm{P}_{4}$ enhanced $P P O$ gene expression (100, $1000 \mathrm{nM}$ ) (Fig. 2a). On days 10 to 11 of the oestrous cycle, $\mathrm{P}_{4}$ inhibited myometrial $P P O$ gene expression (10, $100,1000 \mathrm{nM})$, but increased OXA secretion $(10 \mathrm{nM})$ (Fig. 2a, b) $(\mathrm{P}<0.05)$.

\section{The effect of $\mathrm{P}_{4}$ on OX1R gene and protein expression in the endometrial and myometrial tissue explants}

In the endometrium, on days 10 to 11 of pregnancy, $\mathrm{P}_{4}$ decreased both, OX1R gene $(10,100,1000 \mathrm{nM})$ and protein (10, $1000 \mathrm{nM}$ ) expression (Fig. 3a, b). Similarly, on days 12 to 13 of pregnancy, $P_{4}(10,100,1000 \mathrm{nM})$ caused a decrease in the receptor gene expression and protein content (Fig. 3a, b). On days 15 to 16 of gestation, $\mathrm{P}_{4}$ at the dose of $1000 \mathrm{nM}$ increased, but at the dose of $100 \mathrm{nM}$ decreased the endometrial OX1R gene expression. On those days, $\mathrm{P}_{4}(10,1000 \mathrm{nM})$ suppressed 


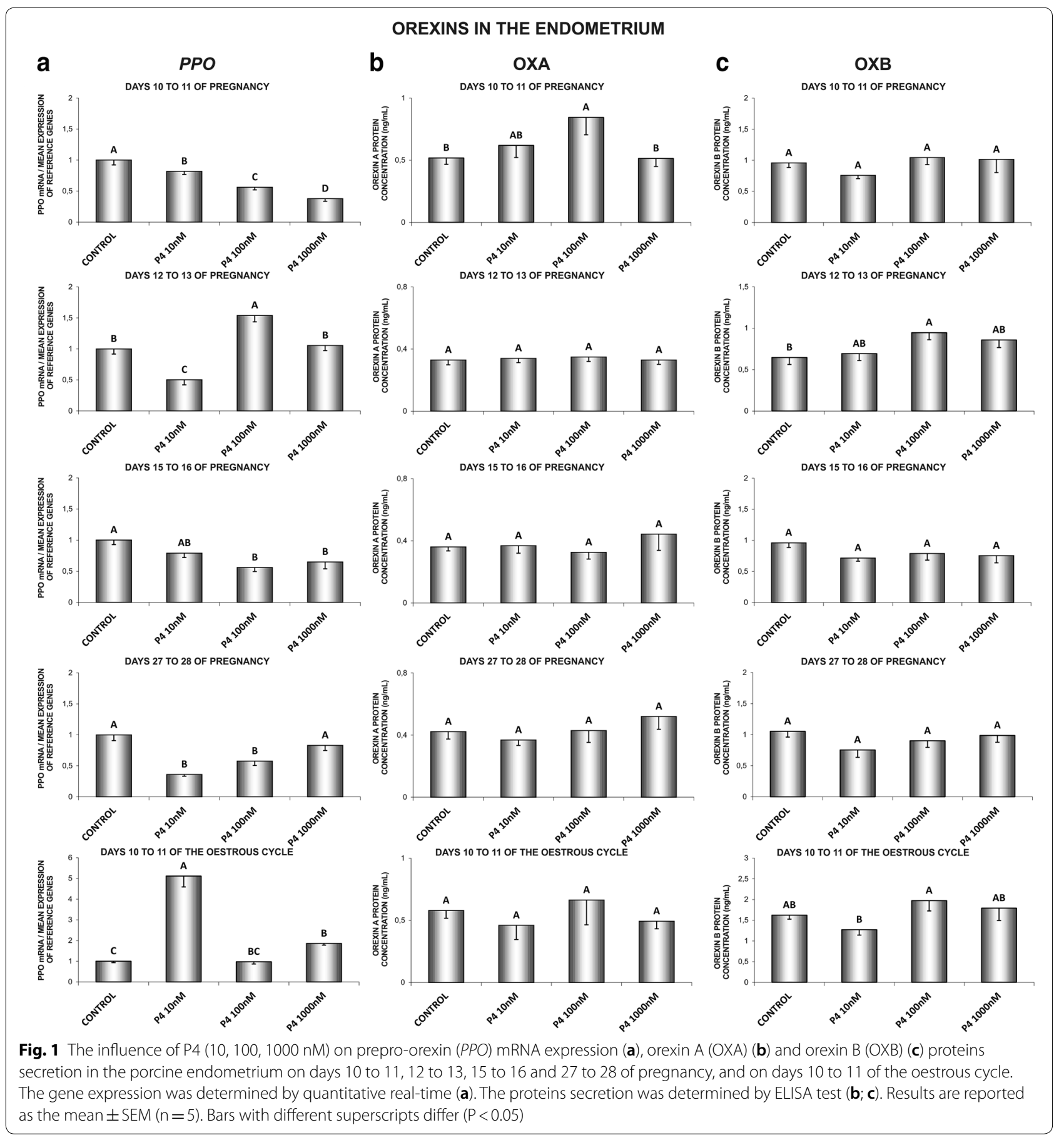

the receptor protein expression (Fig. 3a, b). On days 27 to 28 of gestation, $\mathrm{P}_{4}(10 \mathrm{nM})$ decreased $O X 1 R$ gene expression (Fig. 3a). On those days, $\mathrm{P}_{4}$ at the dose of $10 \mathrm{nM}$ decreased, but at the doses of 100 and $1000 \mathrm{nM}$ increased OX1R protein concentration (Fig. 3b). On days 10 to 11 of the oestrous cycle, $\mathrm{P}_{4}$ at the dose of $10 \mathrm{nM}$ increased, but at the dose of $100 \mathrm{nM}$ decreased OX1R mRNA content (Fig. 3a). On those days, $\mathrm{P}_{4}(10$,
$100 \mathrm{nM})$ decreased the receptor protein concentration (Fig. 3b) $(\mathrm{P}<0.05)$.

In the myometrium, on days 10 to 11 of gestation, $\mathrm{P}_{4}$ caused an increase in $O X 1 R$ mRNA content (100 $\mathrm{nM})$ (Fig. 4a). On days 12 to 13 of pregnancy, $\mathrm{P}_{4}$ at the doses of 10 and $100 \mathrm{nM}$ increased, but at the dose of $1000 \mathrm{nM}$ decreased the receptor gene expression. On those days, $\mathrm{P}_{4}(10 \mathrm{nM})$ caused an increase in OX1R protein 


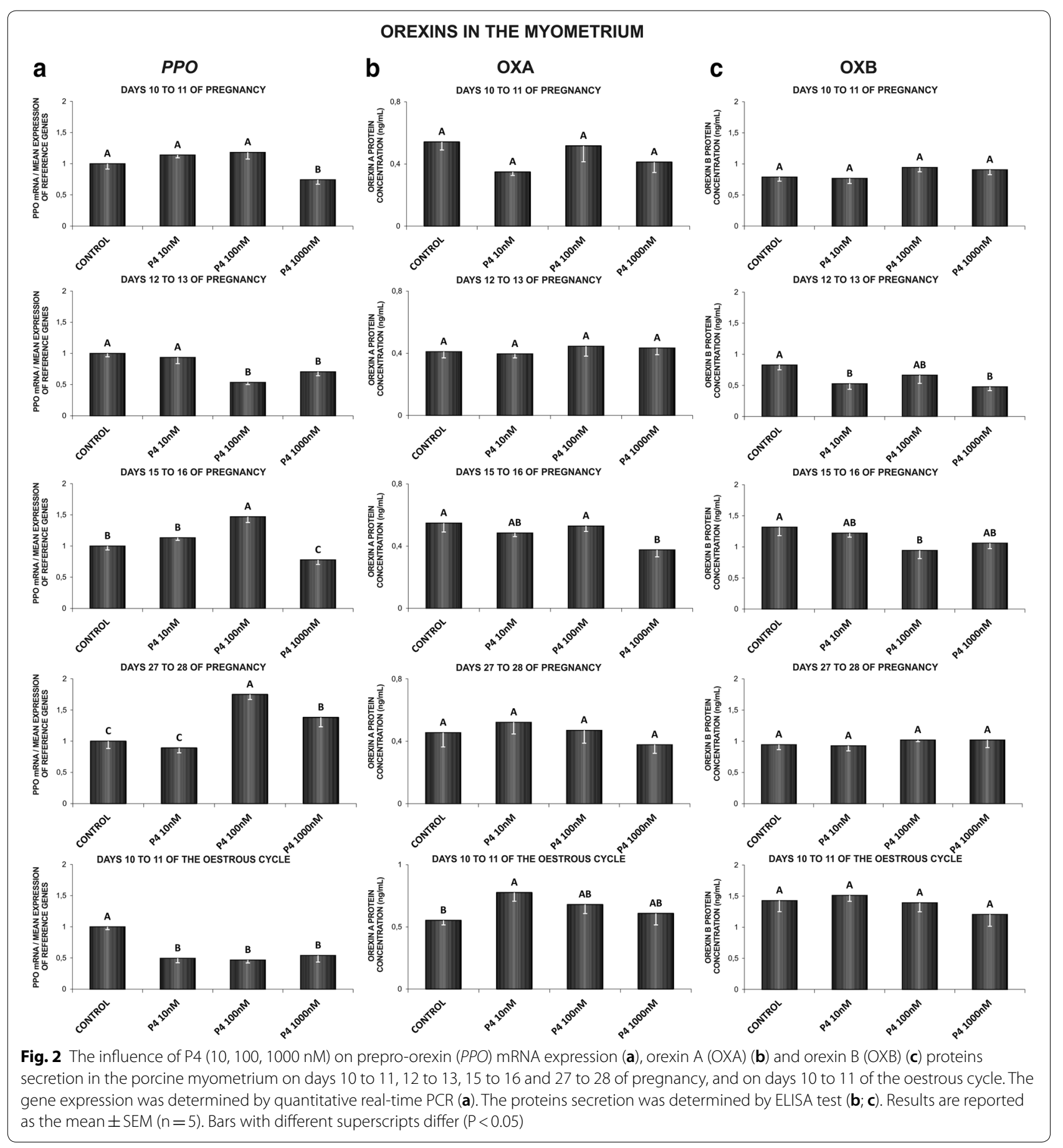

(See figure on next page.)

Fig. 3 The influence of $\mathrm{P} 4(10,100,1000 \mathrm{nM})$ on orexin type 1 receptor (OX1R) mRNA (a) and protein (b) expression in the porcine endometrium on days 10 to 11,12 to 13,15 to 16 and 27 to 28 of pregnancy, and on days 10 to 11 of the oestrous cycle. The gene expression was determined by quantitative real-time PCR (a). The protein concentration was determined by the western blotting analysis (b); upper panels: representative immunoblots (MM - molecular marker); lower panels: densitometric analysis of OX1R protein relative to actin protein. Results are reported as the mean $\pm \operatorname{SEM}(n=5)$. Bars with different superscripts differ $(P<0.05)$ 


\section{OX1R IN THE ENDOMETRIUM}

MRNA RELATIVE EXPRESSION

PROTEIN EXPRESSION

a

DAYS 10 TO 11 OF PREGNANCY
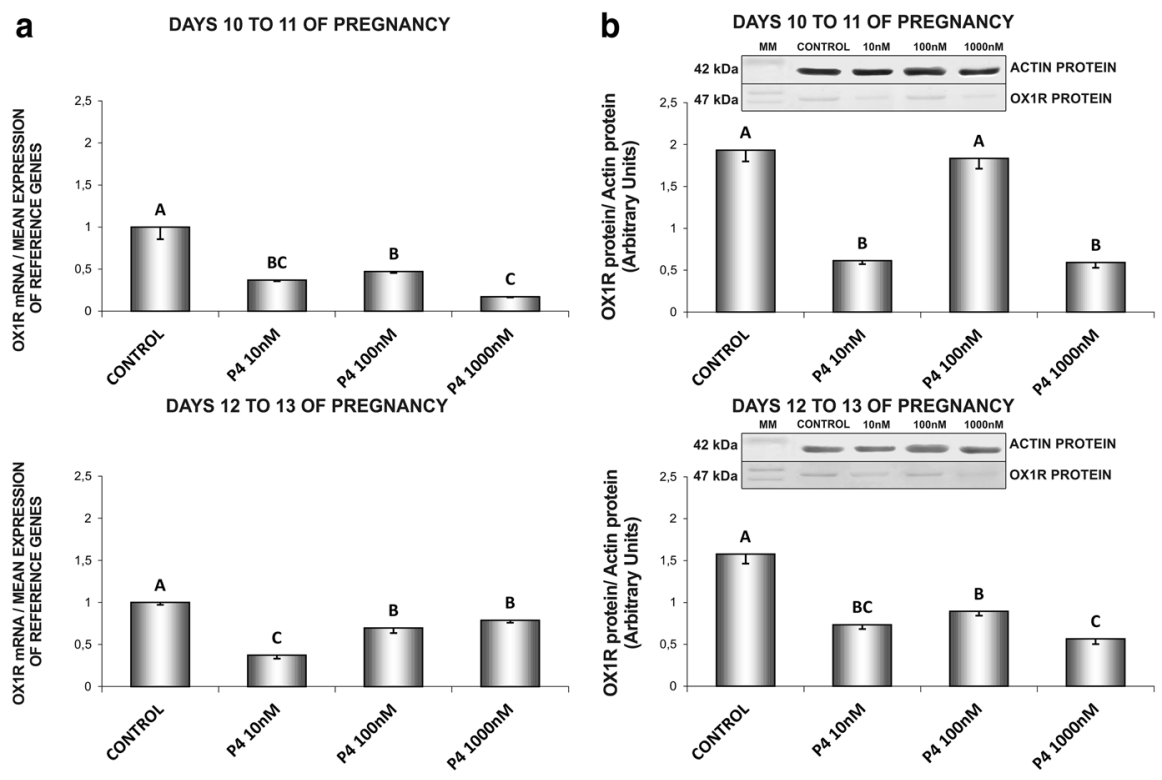

DAYS 15 TO 16 OF PREGNANCY
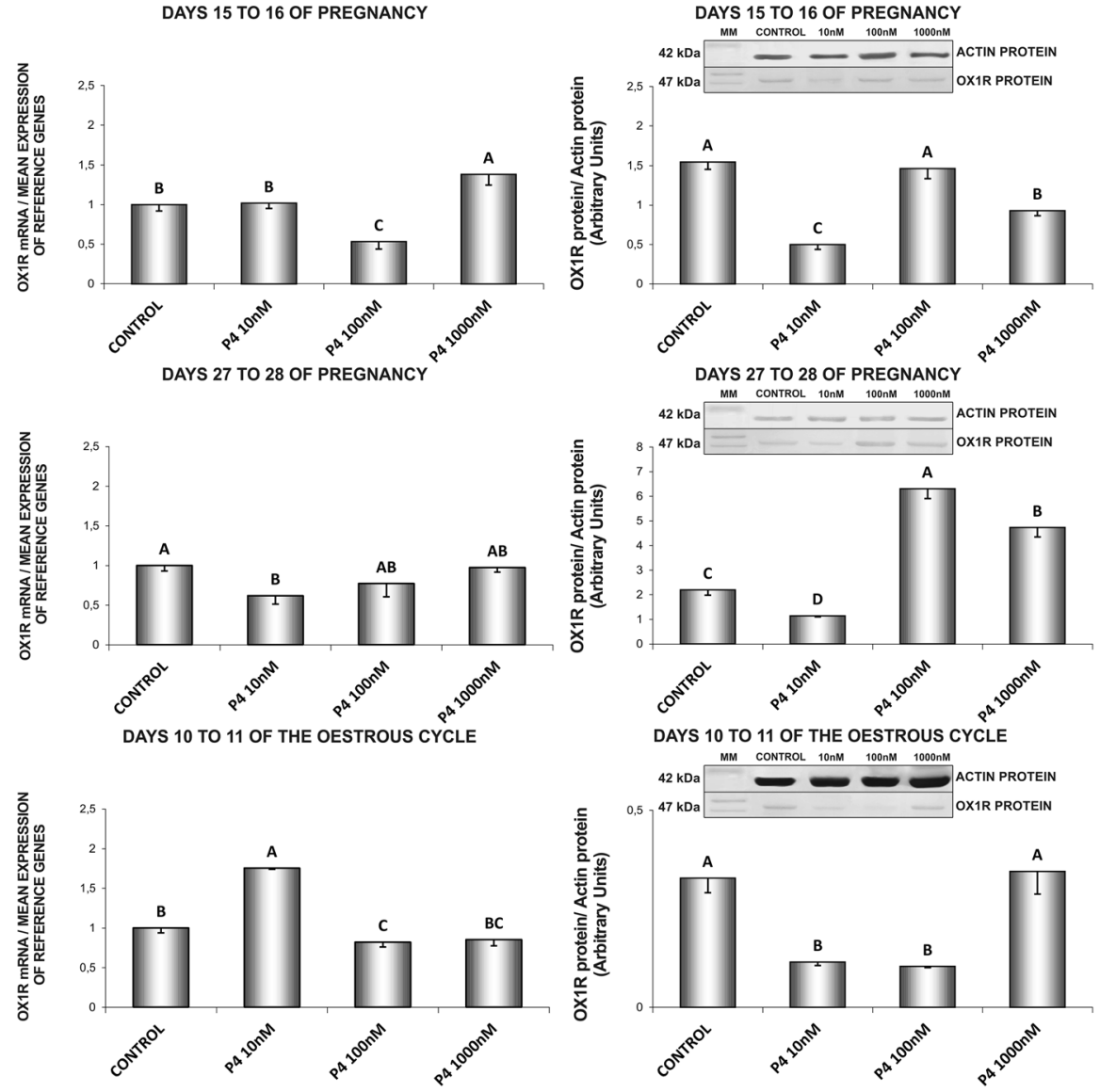
OX1R IN THE MYOMETRIUM MRNA RELATIVE EXPRESSION

PROTEIN EXPRESSION
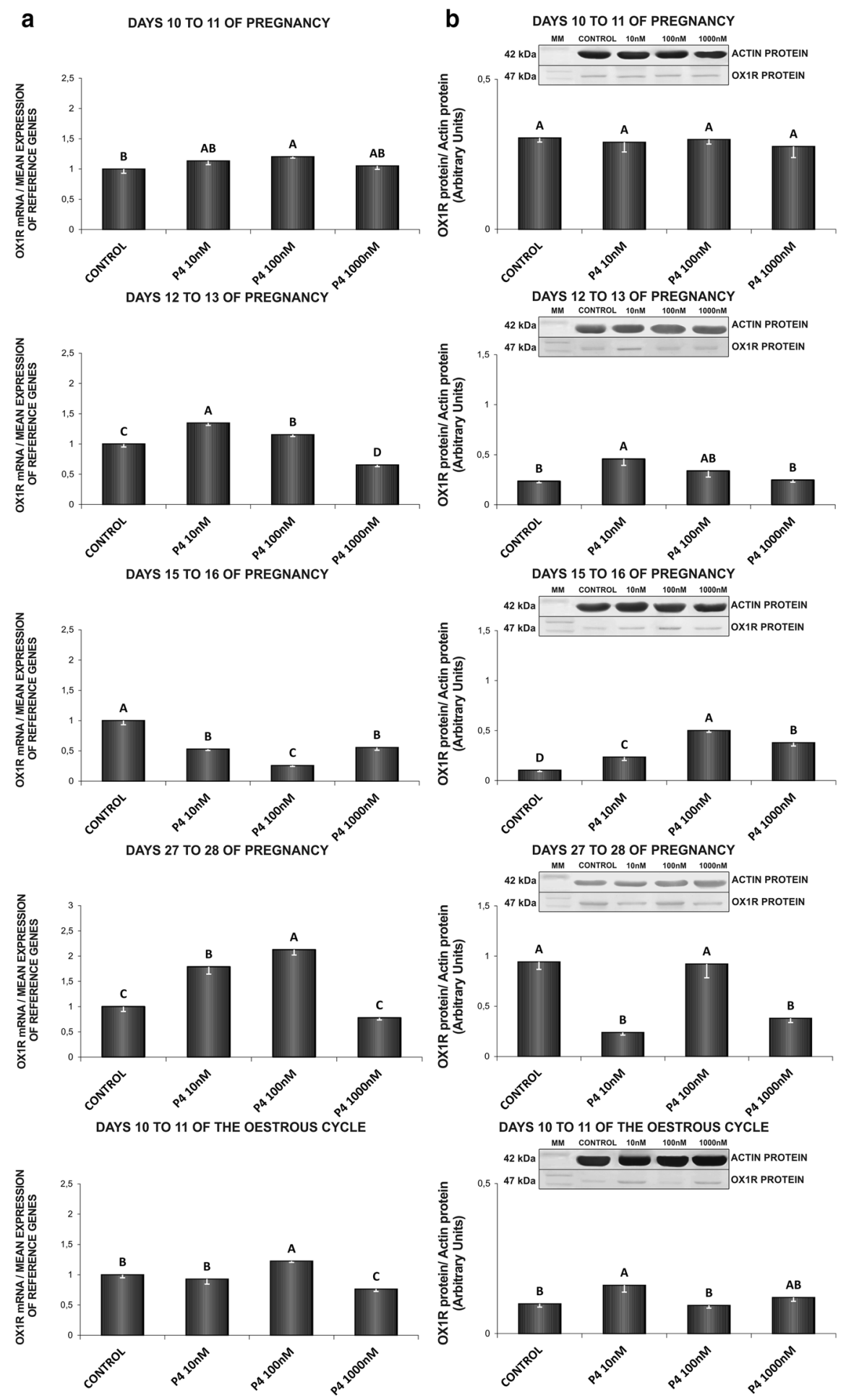
(See figure on previous page.)

Fig. 4 The influence of P4 (10, 100, $1000 \mathrm{nM})$ on orexin type 1 receptor (OX1R) mRNA (a) and protein (b) expression in the porcine myometrium on days 10 to 11,12 to 13,15 to 16 and 27 to 28 of pregnancy, and on days 10 to 11 of the oestrous cycle. The gene expression was determined by quantitative real-time PCR (a). The protein concentration was determined by the western blotting analysis (b); upper panels: representative immunoblots (MM-molecular marker); lower panels: densitometric analysis of OX1R protein relative to actin protein. Results are reported as the mean $\pm \operatorname{SEM}(n=5)$. Bars with different superscripts differ $(P<0.05)$

concentration in the myometrium (Fig. 4a, b). On days 15 to 16 of pregnancy, $\mathrm{P}_{4}$ inhibited $O X 1 R$ gene expression $(10,100,1000 \mathrm{nM})$, but enhanced the receptor protein expression (10, 100, $1000 \mathrm{nM})$ (Fig. 4a, b). Contrary, on days 27 to 28 of gestation, $\mathrm{P}_{4}$ increased OX1R mRNA content $(10,100 \mathrm{nM})$ and decreased the receptor protein expression (10, $1000 \mathrm{nM}$ ) (Fig. 4a, b). Progesterone, at the dose of $100 \mathrm{nM}$ increased, whereas at the dose of $1000 \mathrm{nM}$ decreased the myometrial OX1R mRNA content on days 10 to 11 of the oestrous cycle. On those days, $\mathrm{P}_{4}(10 \mathrm{nM})$ enhanced OX1R protein content (Fig. 4a, b) $(\mathrm{P}<0.05)$.

\section{The effect of $\mathrm{P}_{4}$ on OX2R gene and protein expression in the endometrial and myometrial tissue explants}

In the endometrium, on days 10 to 11 of gestation, $\mathrm{P}_{4}$ at all tested doses caused a decrease in $O X 2 R$ mRNA content. On those days, $\mathrm{P}_{4}$ at the dose of $100 \mathrm{nM}$ increased OX2R protein concentration, but at the doses of 10 and $1000 \mathrm{nM}$ decreased the receptor protein expression (Fig. 5a, b). On days 12 to 13 of gestation, $\mathrm{P}_{4}(10$, $1000 \mathrm{nM}$ ) stimulated $O X 2 R$ gene expression. On those days, $\mathrm{P}_{4}$ at the dose of $100 \mathrm{nM}$ increased, but at the doses of 10 and $1000 \mathrm{nM}$ decreased the receptor protein concentration (Fig. 5a, b). On days 15 to 16 of pregnancy, $\mathrm{P}_{4}(10,100,1000 \mathrm{nM})$ decreased the endometrial OX2R protein concentration (Fig. 5b). On days 27 to 28 of gestation, $\mathrm{P}_{4}$ suppressed the receptor gene expression (10, $100 \mathrm{nM})$, but enhanced OX2R protein concentration $(1000 \mathrm{nM})$ (Fig. 5a, b). On days 10 to 11 of the oestrous cycle, $\mathrm{P}_{4}$ stimulated $O X 2 R$ gene expression $(100 \mathrm{nM})$ and decreased the receptor protein concentration $(100 \mathrm{nM})$ (Fig. 5a, b) $(\mathrm{P}<0.05)$.

In the myometrium, on days 10 to 11 of gestation, $\mathrm{P}_{4}$ stimulated $O X 2 R$ gene expression $(1000 \mathrm{nM})$ and suppressed the receptor protein expression $(10,1000 \mathrm{nM})$ (Fig. 6a, b). On days 12 to 13 of pregnancy, $\mathrm{P}_{4}$ at the dose of $1000 \mathrm{nM}$ stimulated, but at the dose of $10 \mathrm{nM}$ suppressed $O X 2 R$ gene expression. On those days, $\mathrm{P}_{4}(10$,
$100 \mathrm{nM}$ ) enhanced the receptor protein concentration (Fig. 6a, b). On days 15 to 16 of pregnancy, $\mathrm{P}_{4}$ stimulated $O X 2 R$ gene expression $(10 \mathrm{nM})$ and inhibited the receptor protein content $(10,100,1000 \mathrm{nM})$ (Fig. 6a, b). On days 27 to 28 of pregnancy, $\mathrm{P}_{4}$ at all tested doses inhibited the receptor gene expression. On those days, $\mathrm{P}_{4}$ at the dose of $100 \mathrm{nM}$ stimulated, but at the doses of 10 and $1000 \mathrm{nM}$ inhibited the myometrial OX2R protein expression (Fig. 6a, b). On days 10 to 11 of the oestrous cycle, $\mathrm{P}_{4}$ diminished on both, $O X 2 R$ gene $(10,100,1000 \mathrm{nM})$ and protein $(1000 \mathrm{nM})$ expression (Fig. 6a, b) $(\mathrm{P}<0.05)$.

\section{Discussion}

The expression of the PPO gene, OXA and OXB proteins and OX1R and OX2R genes and proteins in the uterus during the oestrous cycle and early pregnancy has been previously reported $[13,14]$. The orexin system has been localised in the porcine uterus, however, there is a general scarcity of data describing the relationship between orexins and the factors regulating reproductive function, including steroid hormones and prostaglandins. The results of this study indicate that $\mathrm{P}_{4}$ has a modulatory effect on the expression of the orexin system (orexins and their receptors) during early gestation. The modulatory effects of $\mathrm{P}_{4}$ were observed at both gene and protein expression level. In the present study, the influence of $\mathrm{P}_{4}$ on orexins and their receptors was different in each stage of gestation, when compared to the controls. This differences may be caused by differential expression of $\mathrm{P}_{4}$ receptors during the examined periods. What is more, during early pregnancy period uterine tissues undergo an intensive remodelling process to prepare the uterus for the implantation, and placentation [24], what results in different cell populations and, in consequence, different tissues receptivity for $\mathrm{P}_{4}$. The observed effect was also tissue- and dose-dependent. Our study revealed different expression patterns of PPO, OX1R and OX2R genes and proteins, in relation the control samples. The different expression patterns of mRNA and proteins is not

(See figure on next page.)

Fig. 5 The influence of $\mathrm{P} 4(10,100,1000 \mathrm{nM})$ on orexin type 2 receptor (OX2R) mRNA (a) and protein (b) expression in the porcine endometrium on days 10 to 11,12 to 13,15 to 16 and 27 to 28 of pregnancy, and on days 10 to 11 of the oestrous cycle. The gene expression was determined by quantitative real-time PCR (a). The protein concentration was determined by the western blotting analysis (b); upper panels: representative immunoblots (MM-molecular marker); lower panels: densitometric analysis of OX2R protein relative to actin protein. Results are reported as the mean $\pm \operatorname{SEM}(n=5)$. Bars with different superscripts differ $(P<0.05)$ 


\section{OX2R IN THE ENDOMETRIUM}

\section{MRNA RELATIVE EXPRESSION}

\section{PROTEIN EXPRESSION}

a

DAYS 10 TO 11 OF PREGNANCY
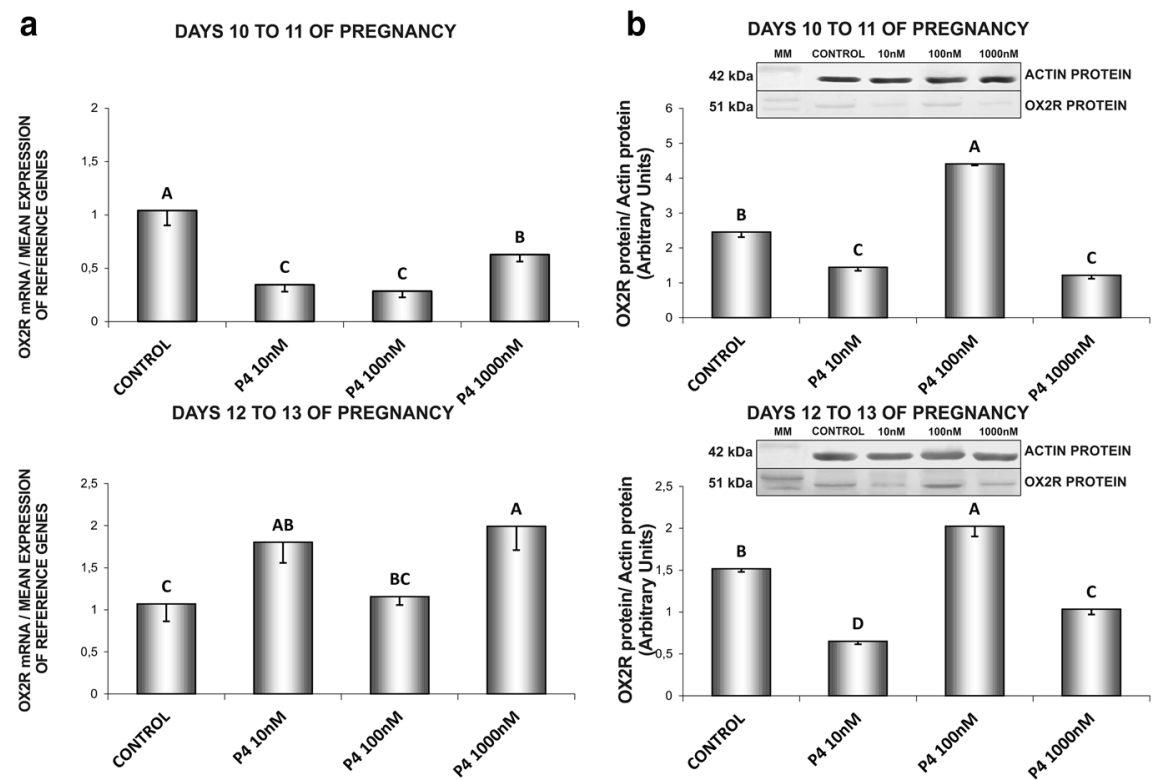

DAYS 15 TO 16 OF PREGNANCY
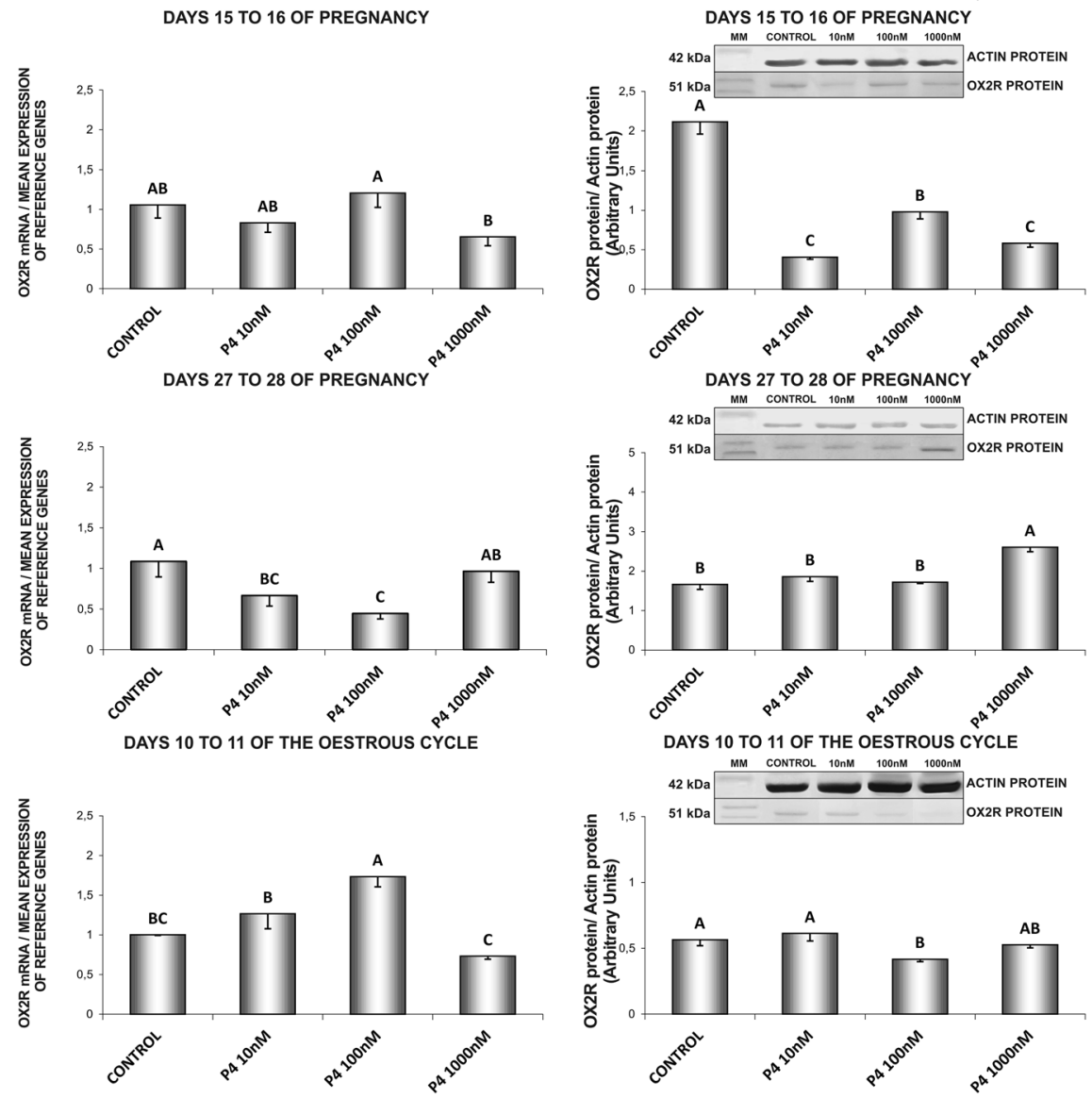


\section{OX2R IN THE MYOMETRIUM}

MRNA RELATIVE EXPRESSION

\section{PROTEIN EXPRESSION}

a

DAYS 10 TO 11 OF PREGNANCY

b DAYS 10 TO 11 OF PREGNANCY
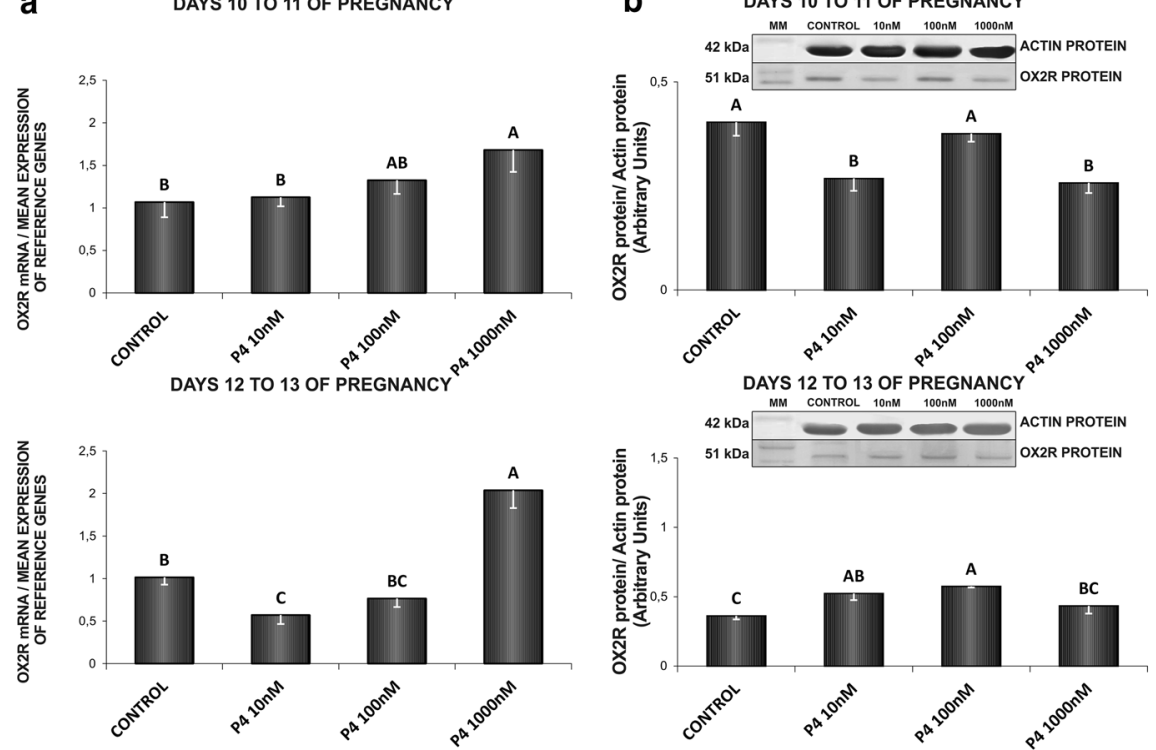

DAYS 15 TO 16 OF PREGNANCY
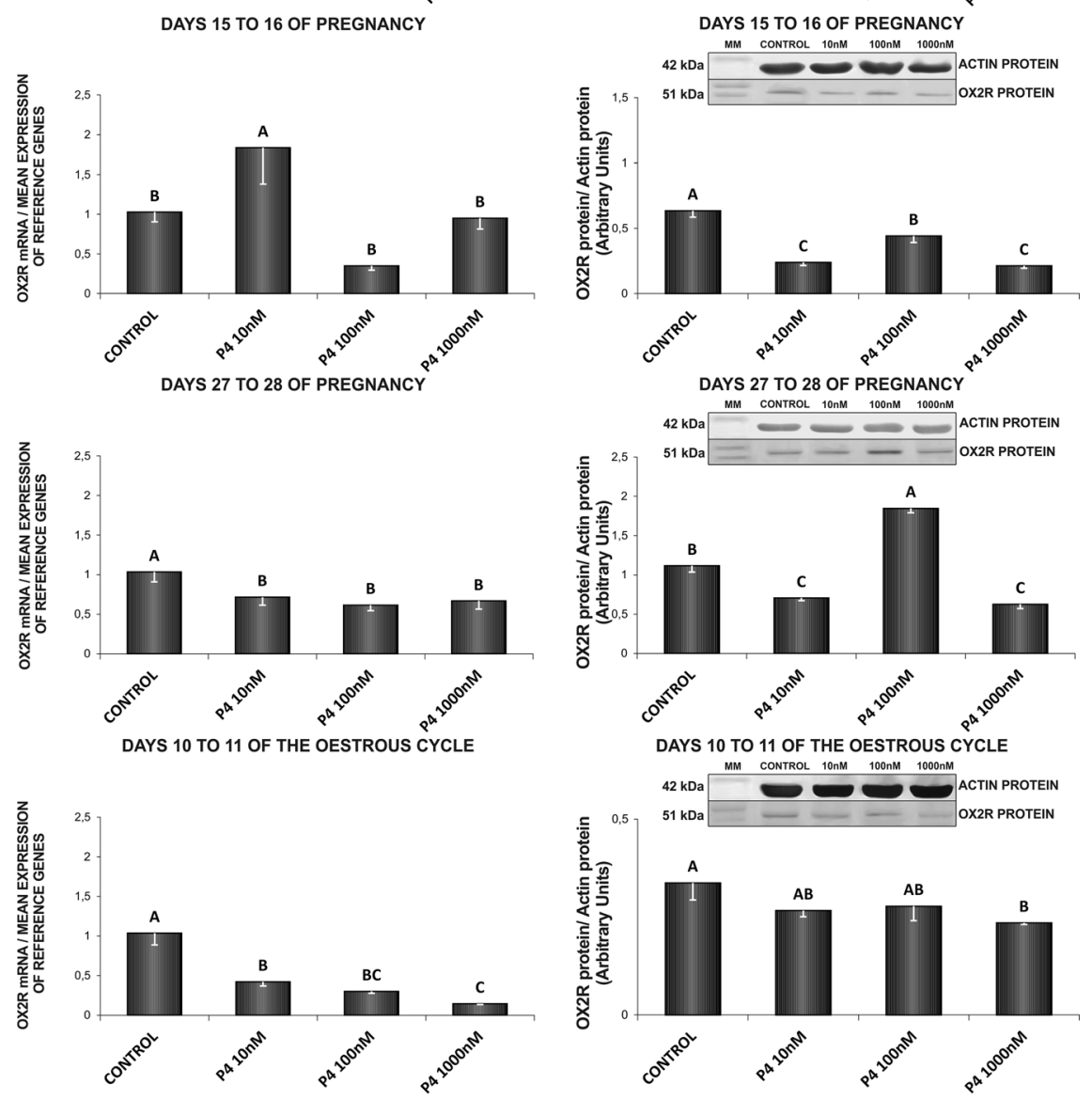
(See figure on previous page.)

Fig. 6 The influence of P4 (10, 100, $1000 \mathrm{nM})$ on orexin type 2 receptor (OX2R) mRNA (a) and protein (b) expression in the porcine myometrium on days 10 to 11,12 to 13,15 to 16 and 27 to 28 of pregnancy, and on days 10 to 11 of the oestrous cycle. The gene expression was determined by quantitative real-time PCR (a). The protein concentration was determined by the western blotting analysis (b); upper panels: representative immunoblots ( $M M$ - molecular marker); lower panels: densitometric analysis of OX2R protein relative to actin protein. Results are reported as the mean \pm SEM $(n=5)$. Bars with different superscripts differ $(P<0.05)$

surprising. In mammals, the correlation between genes and proteins expression can be as low as $40 \%$, and it is influenced by many factors, including mRNA and protein stability, transcriptional and post-transcriptional regulation, functioning feedbacks that suppress gene expression through high protein concentrations, and attenuation of post-transcriptional processes through high mRNA content $[25,26]$.

In mammals, the lifespan of the corpus luteum (CL) has to be extended for continued $\mathrm{P}_{4}$ production and the establishment of a successful pregnancy. The maintenance of $\mathrm{P}_{4}$ secretion is pivotal for the development of the conceptus and implantation [25]. Oestrogens are produced by porcine conceptuses on around day 11 of pregnancy, they initiate changes in the secretion of the main luteolytic factor, prostaglandin $\mathrm{F}_{2 \alpha}\left(\mathrm{PGF}_{2 \alpha}\right)$, from endocrine to exocrine secretion, and increase the production of prostaglandin $\mathrm{E}_{2}\left(\mathrm{PGE}_{2}\right)$, a luteoprotective mediator $[15,27]$. The main aim of the oestrogen-induced decrease in $\mathrm{PGF}_{2 \alpha}$ concentration in uterine venous blood is to protect $\mathrm{CL}$, maintain uninterrupted synthesis of $\mathrm{P}_{4}$ and, consequently, to guarantee the proper course of gestation [15]. The ovaries are the main source of $\mathrm{P}_{4}$ in the body, but the hormone may be also synthesized by uterine tissues. Our previous study demonstrated that despite the decrease in the blood plasma concentration of $\mathrm{P}_{4}$ during early pregnancy, $\mathrm{P}_{4}$ levels in uterine luminal fluid remained constant between days 12 to 28 of gestation and were even higher in comparison with days 10 to 11 of pregnancy [18]. The steroidogenic activity of the porcine endometrium and myometrium was reported by Franczak [19]. Wojciechowicz et al. [28] and Smolinska et al. [20] observed the expression of $3 \beta$-hydroxysteroid dehydrogenase $/ \Delta 5-\Delta 4$ isomerase and $\mathrm{P}_{4}$ secretion by endometrial and myometrial tissues during both early pregnancy and the oestrous cycle. For more, Wojciechowicz et al. [18] indicated, that during early pregnancy the uterine tissues release daily about $2000 \mathrm{pg}$ of $\mathrm{P}_{4}$ per gram of uterus. The above suggest that uterine tissues may play an important role as an alternative source of $\mathrm{P}_{4}$.

Orexins are the physiological mediators of food intake and appetite [2]. Fasting and insulin-induced hypoglycaemia have been found to increase $P P O$ mRNA in the rat lateral hypothalamic area [2, 29]. Lu et al. [30] also demonstrated that fasting regulates the hypothalamic expression of orexin receptors. Most research investigating the role of orexins in food intake focuses on the central nervous system. Generally, an increase in orexin concentrations in the brain stimulates appetite and food deprivation results in an increased expression of the orexin system in the brain [30-33]. Karteris et al. [34] observed considerable differences between orexin receptors in the adrenal cortex and the hypothalamus of rats. In the hypothalamus, food deprivation induced OX1R and OX2R expression at both gene and protein level, whereas in the adrenal glands, OX1R and OX2R concentrations were significantly reduced in food-deprived animals. Based on the above findings, we hypothesized that a similar response may take place in the uterus when rapid embryonic development leads to energy depletion. In the present study, $\mathrm{P}_{4}$ inhibited the expression of OX1R protein in nearly all analyzed periods, whereas the expression of OX2R protein was inhibited only on days 15 to 16 of gestation. Our results suggest that $\mathrm{P}_{4}$ could influence orexins indirectly by modulating the expression of their receptors. Our previous study revealed that orexins could affect steroidogenesis in the porcine uterus. Both OXA and OXB modulated the expression of genes encoding key steroidogenic enzymes, cytochrome P450c17 and cytochrome $\mathrm{P} 450$ aromatase, in endometrial and myometrial tissues. OXA and OXB also regulated the secretion of oestrone, oestradiol and testosterone by uterine tissues in a dose-dependent manner. The influence of both orexins differed between the investigated periods of gestation, which could be attributed to changes in the concentrations of OX1R and OX2R and the OX1R:OX2R ratio $[35,36]$. Progesterone could also be involved in the autoregulation of steroidogenesis by controlling orexin receptivity in the uterus.

Gestation is a critical period for both the mother and the foetus, and its proper course depends on a number of maternal factors. The maternal organism supplies nutrients such as glucose, amino acids and lipids to the developing embryo via the placenta [37]. In mammals, numerous metabolic changes, such as adaptation of carbohydrate metabolism, occur during pregnancy. During gestation, progressive insulin resistance inhibits maternal glucose utilization and increases glucose transport to the foetus. Low glucose levels may increase the risk of miscarriage by depriving the placenta and the foetus of the principal substrate for growth [38-40]. Progressive insulin resistance during normal gestation is 
associated with an increase in maternal $\mathrm{P}_{4}$ serum levels. Orexins exert similar effects on insulin and carbohydrate metabolism. Nowak et al. [41] observed that both orexins stimulate insulin secretion by rat pancreatic cells, both in vivo and in vitro. In the current study, $\mathrm{P}_{4}$ had a minor stimulating effect on OXA (on days 10 to 11 of gestation) and OXB (on days 12 to 13 of gestation) secretion by the endometrium. It is also possible that orexin levels increase during embryo migration and early recognition of pregnancy to prepare the endometrium for implantation. However, the $\mathrm{P}_{4}$-mediated decrease in the concentrations of both orexin receptors during implantation could also desensitise the endometrium to orexins and promote insulin resistance, characteristic for normal gestation.

Orexins participate in the regulation of reproductive function by influencing the hypothalamic-pituitary-ovarian axis. Our previous findings [13, 14] indicate that the orexin system is expressed in the porcine uterus and is dependent on the local hormonal milieu. Progesterone could be responsible for the local regulation of orexin activity during pregnancy. In another study (Smolinska et al., data unpublished), we demonstrated that other uterine factors, including prostaglandins $\left(E_{2}\right.$ and $\left.F_{2 \alpha}\right)$, oestrone and oestradiol, could participate in the regulation of orexin activity in the uterus. Moreover, we observed that orexins could exert modulatory effects on steroidogenesis in the porcine uterus $[35,36]$. This points to the presence of a local feedback loop between orexins and steroids in a pregnant uterus that could play an important role in the regulation of maternal metabolism during pregnancy. However, further research is needed to validate the above hypothesis.

\section{Conclusions}

The modulatory effects of $\mathrm{P}_{4}$ on the orexin system in a pregnant uterus is reported for the first time. The presented data may contribute to the existing knowledge of the mechanisms linking maternal energy metabolism with the regulation of the reproductive system during pregnancy. The results of this study expand our knowledge of the processes that take place in a pregnant uterus and the role, which $\mathrm{P}_{4}$ and orexins play in the uterus during gestation.

\footnotetext{
Authors' contributions

KD developed the research concept and methods, performed the tissue cultures, participated in data and statistical analysis, prepared the manuscript. NS participated in research concept and methods development, was a major contributor in data analysis and statistical analysis, supervised the manuscript preparation. MK was responsible for samples collection. Major contributor in western blot analysis (technical part). KS was major contributor in quantitative real-time PCR analysis (technical part and analysis of results). ER participated in western blot and ELISA results analysis and data interpretation. KK was a major contributor in ELISA analysis (technical part and analysis of results). MG
}

participated in western blot analysis (technical part and analysis of results). TK participated in research concept and methods development, participated in writing of the manuscript. All authors read and approved the final manuscript.

\section{Acknowledgements}

Not applicable.

\section{Competing interests}

The authors declare that they have no competing interests.

\section{Availability of data and materials}

All data generated or analyzed during this study are available from the corresponding author on reasonable request.

\section{Consent for publication}

Not applicable.

\section{Ethics approval and consent to participate}

All studies were conducted in accordance with ethical standards of the Animal Ethics Committee at the University of Warmia and Mazury in Olsztyn, Poland (Ethics Approval No. 91/2011/DTN).

\section{Funding}

This research was supported by National Science Centre (Projects No: 2011/03/B/NZ9/04187).

\section{Publisher's Note}

Springer Nature remains neutral with regard to jurisdictional claims in published maps and institutional affiliations.

Received: 3 October 2017 Accepted: 17 November 2018

Published online: 26 November 2018

\section{References}

1. De Lecea L, Kilduff TS, Peyron C, Gao X-B, Foye PE, Danielson PE, et al. The hypocretins: hypothalamusspecific peptides with neuroexcitatory activity. Proc Natl Acad Sci USA. 1998;95:322-7.

2. Sakurai T, Amemiya A, Ishii M, Matsuzaki I, Chemelli RM, Tanaka H, et al. Orexins and orexin receptors: a family of hypothalamic neuropeptides and $\mathrm{G}$ protein-coupled receptors that regulate feeding behavior. Cell. 1998:92:573-85.

3. Silveyra P, Lux-Lantos V, Libertun C. Both orexin receptors are expressed in rat ovaries and fluctuate with the estrous cycle: effects of orexin receptor antagonists on gonadotropins and ovulation. Am J Physiol Endocrinol Metab. 2007;293:E977-85.

4. Silveyra P, Catalano PN, Lux-Lantos V, Libertun C. Impact of proestrous milieu on expression of orexin receptors and prepro-orexin in rat hypothalamus and hypophysis: actions of Cetrorelix and Nembutal. Am J Physiol Endocrinol Metab. 2007;292:E820-8.

5. Kaminski T, Smolinska N, Nitkiewicz A, Przala J. Expression of orexin receptors 1 (OX1R) and 2 (OX2R) in the porcine pituitary during the oestrous cycle. Anim Reprod Sci. 2010;117:111-8.

6. Kaminski T, Smolinska N, Nitkiewicz A, Przala J. Expression of orexin receptors 1 (OX1R) and 2 (OX2R) in the porcine hypothalamus during the oestrous cycle. J Physiol Pharmacol. 2010;61:363-71.

7. Nitkiewicz A, Smolinska N, Przala J, Kaminski T. Expression of orexin receptors 1 (OX1R) and 2 (OX2R) in the porcine ovary during the oestrous cycle. Regul Pept. 2010;165:186-90.

8. Maleszka A, Smolinska N, Nitkiewicz A, Kiezun M, Chojnowska K, Dobrzyn $K$, et al. Expression of orexin $A$ and $B$ in the porcine hypothalamus during the oestrous cycle. J Physiol Pharmacol. 2013;64:55-63.

9. Smolinska N, Nitkiewicz A, Maleszka A, Kiezun M, Dobrzyn K, Czerwinska $J$, et al. The effect of the estrous cycle on the expression of prepro-orexin gene and protein and the levels of orexin $A$ and $B$ in the porcine pituitary. Animal. 2014;8:300-7.

10. Nitkiewicz A, Smolinska N, Maleszka A, Chojnowska K, Kaminski T. Expression of orexins and their precursor in the porcine ovary and the 
influence of orexins on ovarian steroidogenesis in pigs. Anim Reprod Sci. 2014;148:53-62.

11. Nakabayashi M, Suzuki T, Takahashi K, Totsune K, Muramatsu Y, Kaneko $C$, et al. Orexin-A expression in human peripheral tissues. Mol Cell Endocrinol. 2003;205:43-50.

12. Dall'Aglio C, Pascucci L, Mercati F, Polisca A, Ceccarelli P, Boiti C. Immunohistochemical detection of the orexin system in the placenta of cats. Res Vet Sci. 2012;92:362-5.

13. Nitkiewicz A, Smolinska N, Maleszka A, Kiezun M, Kaminski T. Localization of orexin A and orexin B in the porcine uterus. Reprod Biol. 2012;12:135-55.

14. Smolinska N, Kiezun M, Dobrzyn K, Szeszko K, Maleszka A, Kaminski T. Expression of the orexin system in the porcine uterus, conceptus and trophoblast during early pregnancy. Animal. 2015;9:1820-31.

15. Bazer FW, Thatcher WW. Theory of maternal recognition of pregnancy in swine based on estrogen controlled endocrine versus exocrine secretion of prostaglandin $F_{2 a}$ by uterine endometrium. Prostaglandins. 1977;14:397-401.

16. Franczak A, Kotwica G. Secretion of estradiol-17b by porcine endometrium and myometrium during early pregnancy and luteolysis. Theriogenology. 2008;69:283-9.

17. Akins EL, Morrissette MC. Gross ovarian changes during estrous cycle of swine. Am J Vet Res. 1968;29:1953-7.

18. Dobrzyn K, Smolinska M, Szeszko K, Kiezun M, Maleszka A, Rytelewska E, et al. Effect of progesterone on adiponectin system in the porcine uterus during early pregnancy. J Anim Sci. 2017;95:338-52.

19. Franczak A. Endometrial and myometrial secretion of androgens and estrone during 550 early pregnancy and luteolysis in pigs. Reprod Biol. 2008:8:213-28.

20. Smolinska N, Dobrzyn K, Kiezun M, Szeszko K, Maleszka A, Kaminski T. Effect of adiponectin on the steroidogenic acute regulatory protein, P450 side chain cleavage enzyme and $3 \beta$-hydroxysteroid dehydrogenase genes expression, progesterone and androstenedione production by the porcine uterus during early pregnancy. J Physiol Pharmacol. 2016:67:443-56

21. Blitek A, Kiewisz J, Waclawik A, Kaczmarek MM, Ziecik AJ. Effect of steroids on HOXA10 mRNA and protein expression and prostaglandin production in the porcine endometrium. J Reprod Dev. 2010;56:643-8.

22. Smolinska N, Dobrzyn K, Maleszka A, Kiezun M, Szeszko K, Kaminski T. Expression of adiponectin and adiponectin receptors 1 (AdipoR1) and 2 (AdipoR2) in the porcine uterus during the oestrous cycle. Anim Reprod Sci. 2014;146:42-54.

23. Smolinska N, Kaminski T, Siawrys G, Przala J. Long form of leptin receptor gene and protein expression in the porcine ovary during the estrous cycle and early pregnancy. Reprod Biol. 2007;7:17-39.

24. Bazer FW, Wu G, Spencer TE, Johnson GA, Burghardt RC, Bayless K. Novel pathways for implantation and establishment and maintenance of pregnancy in mammals. Mol Hum Reprod. 2010;16:135-52.

25. de Sousa Abreu R, Penalva LO, Marcotte EM, Vogel C. Global signatures of protein and mRNA expression levels. Mol BioSyst. 2009;5:1512-26.

26. Gry M, Rimini R, Strömberg S, Asplund A, Pontén F, Uhlén M, et al. Correlations between RNA and protein expression profiles in 23 human cell lines. BMC Genomics. 2009;10:365

27. Akinlosotu BA, Diehl JR, Gimenez T. Prostaglandin E2 counteracts the effects of PGF2 alpha in indomethacin treated cycling gilts. Prostaglandins. 1988;35:81-93.

28. Wojciechowicz B, Kotwica G, Kolakowska J, Franczak A. The activity and localization of $3 \beta$-hydroxysteroid dehydrogenase $/ \Delta(5)-\Delta(4)$ isomerase and release of androstenedione and progesterone by uterine tissues during early pregnancy and the estrous cycle in pigs. J Reprod Dev. 2013;59:49-58.
29. Cai XJ, Widdowson PS, Harrold J, Wilson S, Buckingham RE, Arch JR, et al. Hypothalamic orexin expression: modulation by blood glucose and feeding. Diabetes. 1999:48:2132-7.

30. Lu XY, Bagnol D, Burke S, Akil H, Watson SJ. Differential distribution and regulation of OX1 and OX2 orexin/hypocretin receptor messenger RNA in the brain upon fasting. Horm Behav. 2000;37:335-44.

31. Cai XJ, Denis R, Vernon RG, Clapham JC, Wilson S, Arch JR, et al. Food restriction selectively increases hypothalamic orexin-B levels in lactating rats. Regul Pept. 2001;97:163-8.

32. Sakurai T. Orexins and orexin receptors: implication in feeding behavior. Regul Pept. 1999;85:25-30.

33. López M, Seoane L, García MC, Lago F, Casanueva FF, Señarís R, et al. Leptin regulation of prepro-orexin and orexin receptor mRNA levels in the hypothalamus. Biochem Biophys Res Commun. 2000;269:41-5.

34. Karteris E, Machado RJ, Chen J, Zervou S, Hillhouse EW, Randeva HS. Food deprivation differentially modulates orexin receptor expression and signaling in rat hypothalamus and adrenal cortex. Am J Physiol Endocrinol Metab. 2005;288:E1089-100.

35. Kiezun M, Smolinska N, Dobrzyn K, Szeszko K, Rytelewska E, Kaminski T. The effect of orexin A on CYP17A1 and CYP19A3 expression and on oestradiol, oestrone and testosterone secretion in the porcine uterus during early pregnancy and the oestrous cycle. Theriogenology. 2017:90:129-40.

36. Kaminski T, Smolinska N, Kiezun M, Dobrzyn K, Szeszko K, Maleszka A. Effect of orexin B on CYP17A1 and CYP19A3 expression and oestradiol, oestrone and testosterone secretion in the porcine uterus during early pregnancy and the oestrous cycle. Animal. 2018;12:1921-32.

37. Brett KE, Ferraro ZM, Holcik M, Adamo KB. Prenatal physical activity and diet composition affect the expression of nutrient transporters and mTOR signaling molecules in the human placenta. Placenta. 2015;36:204-12.

38. Bliss CR, Wiedenkeller DE, Sharp GW. Maternal diet and insulin secretion in islets of lactating, nonlactating, and young rats. Am J Physiol. 1990;259:E568-75.

39. Parsons JA, Brelje TC, Sorenson RL. Adaptation of islets of Langerhans to pregnancy: increased islet cell proliferation and insulin secretion correlates with the onset of placental lactogen secretion. Endocrinology. 1992;130:1459-66.

40. Baaziz N, Curry DL. Synthesis-secretion coupling of insulin: effect of pregnancy and lactation. Pancreas. 1993;8:316-24.

41. Nowak KW, Maćkowiak P, Switońska MM, Fabiś M, Malendowicz LK. Acute orexin effects on insulin secretion in the rat: in vivo and in vitro studies. Life Sci. 2000;66:449-54.

42. Lord E, Ledoux S, Murphy BD, Beaudry D, Palin MF. Expression of adiponectin and its receptors in swine. J Anim Sci. 2005;83:565-78.

43. Spagnuolo-Weaver M, Fuerst R, Campbell ST, Meehan BM, McNeilly F, Adair B, et al. A fluorimeter-based RT-PCR method for the detection and quantitation of porcine cytokines. J Immunol Methods. 1999;230:19-27.

Ready to submit your research? Choose BMC and benefit from

- fast, convenient online submission

- thorough peer review by experienced researchers in your field

- rapid publication on acceptance

- support for research data, including large and complex data types

- gold Open Access which fosters wider collaboration and increased citations

- maximum visibility for your research: over $100 \mathrm{M}$ website views per year

At BMC, research is always in progress.

Learn more biomedcentral.com/submissions 